\title{
Innovative Model of Environmental Engineering Microbiology Experiments Coupling with Classroom Teaching
}

\author{
Ming ZENG \\ College of Marine and Environment \\ Tianjin University of Science and Technology \\ Tianjin, China \\ ming.zeng@tust.edu.cn \\ Chang WANG \\ College of Marine and Environment \\ Tianjin University of Science and Technology \\ Tianjin, China \\ wangc88@163.com
}

\author{
Qingzhu JIA \\ College of Marine and Environment \\ Tianjin University of Science and Technology \\ Tianjin, China \\ jiaqingzhu@tust.edu.cn \\ Nan WU* (Corresponding author) \\ College of Engineering and Technology \\ Tianjin Agricultural University \\ Tianjin, China \\ nwu@tjau.edu.cn
}

\begin{abstract}
The purpose of this study is to change the education mode of independent experimental teaching and classroom teaching in environmental engineering microbiology. By coupling these two teaching ways, the teaching efficiency and quality will be improved. Firstly, the contents of experimental teaching were optimized by increasing the ratio of general type and research type experiments. Then the methods of reforming experimental teaching were proposed through adding characteristic contents of subject. Based on the reformation, the methods and direction of coupling experimental teaching and classroom teaching were presented. Finally, the ratio of examination of experimental teaching was increased.
\end{abstract}

Keywords-Environmental Engineering Microbiology; Teaching Reform; Experiment Teaching; Innovative Model

\section{INTRODUCTION}

Environmental engineering microbiology is a compulsory basic course for students majoring in environmental engineering. The purpose is to enable students to master the basic theory system of microbiology, and familiar with the effect of microorganisms in wastewater treatment, biological treatment of solid waste, as well as during the process of pollution and self-purification of water, soil and air. This course is an interdisciplinary subject of environmental science and biology, and the knowledge points are relatively scattered and developed rapidly $[1,2]$. Therefore, we need to explore and reform the teaching contents and teaching methods according to the subject development. The general course consists of two parts: classroom teaching and experimental teaching. However these two parts are often relatively independent. Therefore, the purpose of this paper is to explore a new teaching mode, combining classroom teaching and experimental teaching, in order to improve the efficiency and quality of teaching.

\section{TRADITIONAL EXPERIMENT TEACHING REFORM}

\section{A. Optimization Design of Experiment Teaching Contents}

There are 4 levels of experimental contents in the experiment teaching, that is, the verification experiment, the comprehensive experiment, the research design experiment and the productive practice experiment. Among them, the experiments related to the culture medium preparation, utensils and medium sterilization, microscope operation, microbial staining and observation, microbial culture and separation are essential. Meanwhile, these experiment contents are the most basic microbiology experiments whose operation must be mastered [3]. In addition, at present, there are relatively more verification and operation experiments, but lack of research design and comprehensive experiments. This experimental system is not conducive to the cultivation of students' practical ability and the development of scientific thinking [4]. Consequently, it is necessary to design comprehensive experiments and research experiments to improve students' ability to discover, analyze and solve problems.

According to the actual situation, the experimental class is designed for 20 hours. Among them, verification experiments are set to 14 hours, which accounts for the largest proportion $(70 \%)$, as shown in Fig. 1. Comprehensive and productive practice experiments and research design experiments occupy a relatively small proportion, equal to $10 \%$ and $20 \%$, respectively. 


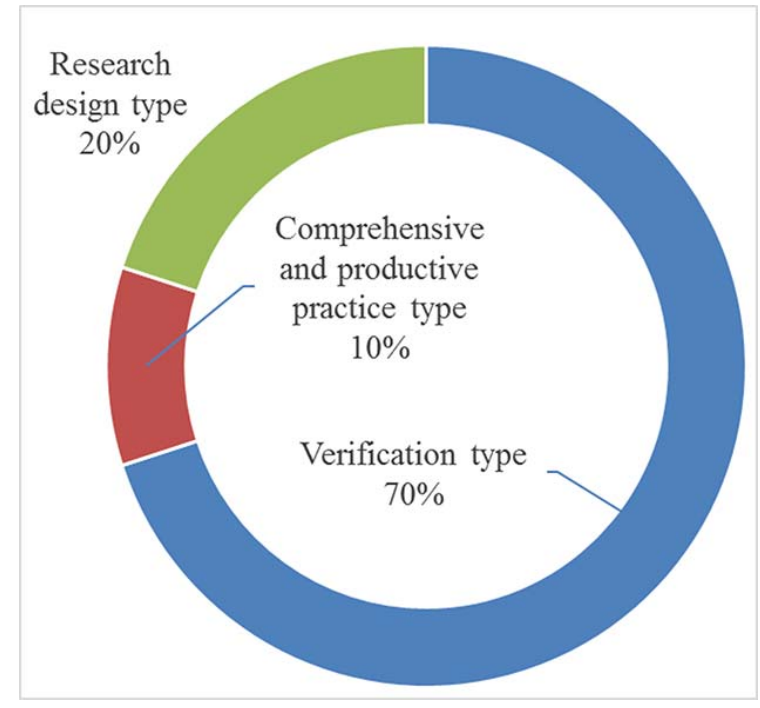

Fig. 1. Proportion of experimental properties

Table 1 summarizes the optimized experimental teaching contents. In addition to the 14 hours of routine environmental engineering microbiology experimental contents, 2-hour comprehensive and productive practice experiment is also integrated. This experiment requires students to select any object according to their interests, such as mobile phone, door handles, paper money and other items in daily life. And students can observe the possible microbial species on these items through microbial enrichment and cultivation methods. Moreover, 4-hour experiment of contaminant tolerant bacteria screening is added. This experiment belongs to the research design experiment. Students can design their own experiments to screen pollutant tolerant bacteria, according to the current hot issues, such as the discovery of drug-resistant bacteria, screening of heavy metal resistant bacteria.

TABLE I. EXPERIMENTAL TEACHING CONTENTS OF ENVIRONMENTAL ENGINEERING MICROBIOLOGY AFTER OPTIMIZATION DESIGN

\begin{tabular}{|c|c|c|c|}
\hline & Experiment name & Properties & $\begin{array}{c}\text { Planning } \\
\text { hours }\end{array}$ \\
\hline 1 & $\begin{array}{c}\text { The operation of optical } \\
\text { microscope, and the } \\
\text { morphological observation of } \\
\text { actinomycetes, fungi and algae }\end{array}$ & $\begin{array}{c}\text { Verification } \\
\text { type }\end{array}$ & 2 \\
\hline 2 & Microbial staining & $\begin{array}{c}\text { Verification } \\
\text { type }\end{array}$ & 2 \\
\hline 3 & $\begin{array}{c}\text { Preparation and sterilization of } \\
\text { culture medium }\end{array}$ & $\begin{array}{c}\text { Verification } \\
\text { type }\end{array}$ & 2 \\
\hline 4 & $\begin{array}{c}\text { Determination of total bacteria in } \\
\text { water }\end{array}$ & $\begin{array}{c}\text { Verification } \\
\text { type }\end{array}$ & 4 \\
\hline 5 & $\begin{array}{c}\text { Enrichment and purification of } \\
\text { microorganisms from any subject }\end{array}$ & $\begin{array}{c}\text { Comprehensive } \\
\text { and productive } \\
\text { practice type }\end{array}$ & 2 \\
\hline 6 & $\begin{array}{c}\text { Detection of fecal coliform in } \\
\text { water }\end{array}$ & $\begin{array}{c}\text { Verification } \\
\text { type }\end{array}$ & 4 \\
\hline 7 & $\begin{array}{c}\text { Screening of contaminant tolerant } \\
\text { bacteria }\end{array}$ & $\begin{array}{c}\text { Research design } \\
\text { type }\end{array}$ & 4 \\
\hline
\end{tabular}

\section{B. Innovative Practice of Experimental Teaching Methods}

The previous experimental teaching methods are to assign tasks to students in the experimental class. Most of the students just copy things without catching the spirit, and they complete the experiments without independent thinking. In our practice teaching, we assign the experimental tasks to students before the class, so that they can think about how to finish the experiments and make the detailed experiment steps. In the experimental class, teachers just put forward the guiding opinions and give more time for the students to do it by themselves. This process can enable students to learn in the experiments, and to deepen the understanding for basic knowledge.

Additionally, undergraduate students are allowed to enter into the laboratory, so that students can visit a variety of anaerobic and aerobic biological reactors, and understand the activated sludges in sewage treatment. The experimental materials can be selected from the scientific equipments in laboratory, such as the acquisition of activated sludge, the observation of bacteria, protozoa and metazoa by microscope, and the determination of total number of bacteria, fecal coliform in inlet and outlet samples collected from the laboratory equipment. Combined with the characteristics of laboratory research, such as partial nitrification, anaerobic ammonium oxidation, the removal of antibiotics and other research direction, the enrichment and cultivation of these new microorganisms can be carried out. It is aimed to enable students to learn forward-looking knowledge and skills, and to keep up with the pace of environmental science development.

\section{EXPloration ON THE COUPLing Mode OF ClassRoom TEACHING AND EXPERIMENT TEACHING}

\section{A. Complement of Two Teaching Forms}

In the past, the experimental teaching is often separated from classroom teaching during the teaching process of environmental engineering microbiology. In this paper, we will introduce the experimental teaching interspersed in the classroom teaching, thus they are no longer two separate teaching systems. The advantage is to enable students to quickly learn the theoretical knowledge and have a more intuitive understanding, which enhances their enthusiasm for learning and learning efficiency.

For example, after completing the study of prokaryotes, eukaryotes and viruses, students are asked to complete two related experiments, as shown in Fig. 2. This allows students to have a perceptual knowledge as soon as possible about those microorganisms that cannot be seen by naked eyes. Meanwhile, this helps students to enhance their understanding and memory of gram staining. In the same way, students begin to do experiments related to culture medium after the study of the metabolism of microorganisms (Fig. 2). Through the preparation of culture medium, students can deepen the understanding for the microbial nutrition conditions and nutrition types. 


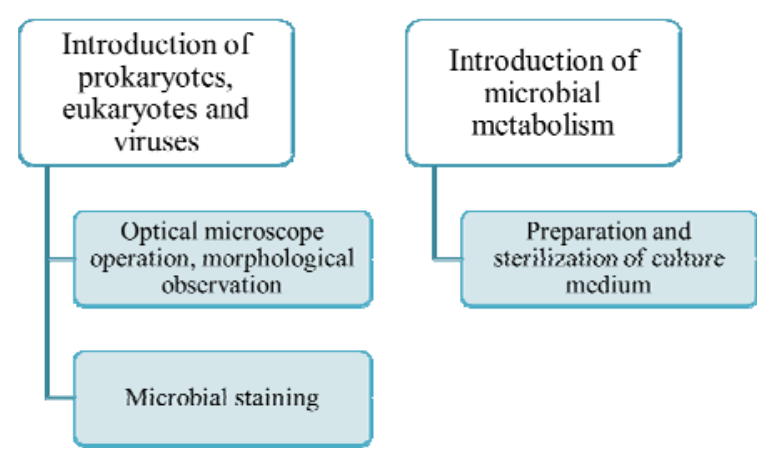

Fig. 2. Coupling of classroom teaching and experimental teaching

On the contrary, if the experimental teaching is carried out after the end of 40-hour classroom teaching, students will forget a lot of knowledge they have learned before. The effect of experimental teaching will be greatly discounted. So it is better to organically combine two teaching methods rather than separate them, and this can often yield twice the result with half the effort. When carrying out experimental class immediately after the end of theory course, students have a more intuitive and profound understanding of the knowledge they have learned, which greatly enhances their interests in the next theoretical knowledge learning.

\section{B. Experimental Case Provided in Classroom Teaching}

Some classic cases of microbiology in the history are introduced into the teaching classroom, such as the experiments of Fleming discovered penicillins, the invention of microbial fuel cells, and a variety of genetically engineered cases. Through the introduction of historical cases, students can develop a scientific way of thinking, and learn to take the initiative to find the problem, rather than blindly repeat the previous work. Students' awareness of innovation can be cultivated while learning basic knowledge.

In the classroom teaching, we use multimedia for the preview work of experimental teaching. Multimedia has the advantages of vivid and large amount of information, which can enable students to better grasp the experimental operation skills. The experimental operation is more standardized, and more intuitive than the simple oral explanation of teachers [5]. Students can also watch video clips after class, which deepen the understanding of experimental operation. Thus students can practice, improve and innovate in the experimental class.

In the late stage of 40-hour classroom teaching, the application of microorganisms in pollution control of water, air and solid waste are introduced. This part of knowledge is very important, and directly influences the extent of mastering basic professional knowledge in the future for students. Therefore, it is necessary for students to master the basic principles of microbial removal of various pollutants in the environment, and as soon as possible to understand a variety of biological treatment processes, such as the principle of biological nitrogen removal and phosphorus removal in water pollution control engineering, and the process flow of aerobic and anaerobic bioreactors. On one hand, this requires to encourage students to enter the graduate laboratory to visit and study in the experimental teaching. On the other hand, it is necessary to show the basic theory and process flow to the students in the classroom teaching with pictures and animation. In short, the experiment contents run through every link of the classroom teaching, in order to get rid of the boring theory knowledge.

\section{INNOVATION OF CURRICULUM EVALUATION SYSTEM}

An effective curriculum evaluation system is an important means to evaluate students' knowledge and skills, as well as an important way to check the teaching effectiveness and improve teaching methods [6]. This paper proposes to adjust the proportion of the experimental results in the total score, from the original $20 \%$ to $30 \%$. The adjustment of proportion can make the students pay more attention to the microbiology experiments, and carefully complete each experiment step. Also this can help students to deepen the understanding and memory of knowledge points, and to avoid a simple cramming teaching.

At the same time, homework can be more flexible, to keep up with the development of microbial frontier, such as super bacteria, influenza virus, Zika virus and other social hot spots. Students are required to consult the literature and network information, and to sum up a solution to the problem. In this way, students cannot only review the knowledge they have learned, but also expand the relevant professional knowledge. The corresponding effect is remarkable.

\section{CONCLUSIONS}

The importance of environmental engineering microbiology in environmental science is self-evident, but the difficulty of teaching is also obvious. How to make students master important knowledge points and has the basic skills at the same time through theory teaching and experimental teaching is a proposition which needs to be explored continuously in the teaching practice. The aim of teaching, which should be kept in mind in various teaching links, is to cultivate students' ability to discover problems, analyze problems and solve them. Let students to learn something and to apply what one has learned.

\section{ACKNOWLEDGMENT}

This research was financially supported by Natural Science Foundation of Tianjin (15JCYBJC53700), National Undergraduate Training Programs for Innovation and Entrepreneurship (201610057005), and Educational Reform and Innovation Project of Tianjin Agricultural University (20170103).

\section{REFERENCES}

[1] Y.Q. Le, S.F. Wang, X.C. Tang, J.C. Xu, and Q.Y. Zhou, "Exploration and practice of course construction of environmental engineering microbiology," Bulletin of Microbiology (in Chinese), 2011, vol. 38(9), pp. 1430-1434.

[2] Z.H. Yang, G.M. Zeng, Y.G. Liu, and X. Yang, "Exploration and practice on teaching reform of environmental engineering 
microbiology," University Education Science (in Chinese), 2004, vol. 3, pp. 45-47.

[3] S.B. Pan and H.Q. Sun, "Study on optimization of environmental engineering microbiology experiment teaching," Chinese Journal of Microecology (in Chinese), 2010, vol. 22(9), pp. 841-842.

[4] S.L. Liu, "Research and practice of innovative teaching system of microbiology experiment," Bulletin of Microbiology (in Chinese), 2005, vol. 32(4), pp. 153-155
[5] D.Q. Zhang and H.A. Zheng, "Exploration on teaching reform of environmental engineering microbiology experiment," Chinese Education Innovation Herald (in Chinese), 2011, vol. 26, pp. 26-27.

[6] D.C. Pei, "Experimental teaching reform of medical microbiology," Basic Medical Education (in Chinese), 2005, vol. 7(5), pp. 522-524. 